\title{
Analysis on International Competitiveness of Mechanical and Electrical Products in China
}

\author{
Yajun Sun \\ College of Jincheng \\ Nanjing University of Aeronautics and Astronautics \\ Nanjing, China
}

\begin{abstract}
Mechanical and electrical products play an important role in international trade export and have become powerful support of foreign trade in China. The international competitiveness level of it plays a crucial role in promoting overall level of international competitiveness of China. Measuring international competitiveness of mechanical and electrical products in China through international market share and revealed comparative advantage index, it is found that international competitiveness level of mechanical and electrical products in China is relatively high, but exported products are still labor intensive with low added value and lack technological innovative ability. Therefore, in order to improve export competitiveness of mechanical and electrical products in China, it is necessary to improve technological innovative ability, implement diversified market strategy and set up brand consciousness.
\end{abstract}

Keywords-mechanical and electrical products; revealed comparative advantage index; international competitiveness

\section{INTRODUCTION}

Mechanical and electrical product exporting plays an extremely important role in commodity export of China. According to statistics of China customs, the total exportimport volume of mechanical and electrical products in China reaches 2,170 billion dollars, with year-on-year growth of $2.8 \%$; total export reaches 1,310 billion dollars, which increase $3.6 \%$ comparing with the same period of last year and occupy $56 \%$ of national total commodity export; total import reaches 850 billion dollars, with year-on-year growth of $1.7 \%$, occupying $43.6 \%$ of national total commodity export. Mechanical and electrical product exporting promotes rapid and fast growth of national economy and plays significant role in promoting foreign trade export. With comparative advantage in labor force and natural resources, labor intensive mechanical and electrical products occupy certain favorable position in international market. However, it is very important task on how about international competitiveness level of mechanical and electrical products in China, what factors influence international competitiveness of mechanical and electrical products in China and how to improve international competitiveness level of mechanical and electrical products in China.

\section{CURRENT SituAtion OF MECHANICAL AND ELECTRICAL PRODUCT EXPORTING}

\section{A. Export Volume of Mechanical and Electrical Products}

After joining the WTO, mechanical and electrical product exporting in China develops rapidly. Mechanical and electrical products become the first pillar export products. Since 2005, total export of mechanical and electrical products in China has presented steadily rising trend. However, influenced by international financial crisis, total export of mechanical and electrical products in 2009 is 713,113 million dollars, with year-on-year reduction of $13.4 \%$. Later it grows steadily once again. In 2013, the value of import and export of mechanical and electrical products in China was 2,100 billion dollars. It breaks through 2,000 billion dollars for the first time. Total export of mechanical and electrical products is 1,260 billion dollars. China becomes the first big exporter of mechanical and electrical products in the world. At the meantime, the value of exports of mechanical and electrical products ranks the first place in the world in four successive years. In 2014 and 2015, although international market had weak demand for mechanical and electrical products, and cost advantage of domestic raw materials and labor force reduced, the growth slowed down to some extent, it still remained the trend of stable growth.

\section{B. Geographical Direction of Mechanical and Electrical Product Exporting}

Geographic direction of mechanical and electrical product exporting in China mainly focuses on EU, America, Hong Kong, Japan and South Korea. Meanwhile, with establishment of China-ASEAN Free Trade Area, ASEAN becomes important trade partner of China.

As main export markets of mechanical and electrical products in China, the amount of exports in America, EU and Hong Kong all broke through 200 billion dollars in 2014. China is the second largest goods trading partner. In recent years, the proportion of total trade volume occupied by China in EU doubles. In 2014, investment of China in EU set a new record. Successful visit of Chinese premier Li Keqiang in Germany, Switzerland and Romania brings substantial results. Prime Minister of UK and Prime Minister of France visit Beijing and sign all kinds of commercial agreement of more 
than 20 billion Euros. It has beneficial effects on exporting of mechanical and electrical products in China.

Chinese mainland is the biggest trade partner of Hong Kong and ranks first among export destinations and sources of import of Hong Kong. Mechanical and electrical products are major products that Hong Kong imports from China mainland, so the amount of amounts still occupies the proportion of nearly $20 \%$. Because the rate of economic growth of Hong Kong reduces and trade surplus of China also reduce by $40.3 \%$, comparing with that of 2013, the amount of exports reduces.

China is the largest trade partner of South Korea and Japan as well as the largest source of imports. Mechanical and electrical products have certain competitive advantage in markets of South Korea and Japan and then it can ensure growth. But influenced by competitors in Italy, America and other regions in Asia, the growth slows down.

\section{ANALYSIS ON INTERNATIONAL COMPETITIVENESS OF MECHANICAL AND ELECTRICAL PRODUCTS}

\section{A. Analysis on Revealed Comparative Advantage}

Revealed Comparative Advantage (RCA) refers to the ratio between the proportion occupied by amount of exports of product in a country in total export of this product and related data of this product in the world. The index is appropriate to evaluate international competitiveness of certain industry in a country.

$$
R C A=\left(X_{i} / X_{t}\right) /\left(W_{i} / W_{t}\right)
$$

In the formula, $\mathrm{Xi}$ refers to export value of a product in a country; Xt refers to gross export value of product in a country; Wi refers to export value of a product in the world; Wt refers to gross export value of product in the world.

When RCA value is greater than 2.5 , it indicates that a product in a country has very strong export competitiveness in international market; when RCA value is between 0.8 and 2.5, it indicates that a product in a country has certain export competitiveness in international market; when RCA value is smaller than 0.8 , it indicates that a product of a country does have export competitiveness in international market. Now choose revealed comparative advantage index of mechanical and transportation equipment in mechanical and electrical products to analyze.
TABLE I. RCA VALUE OF MECHANICAL AND TRANSPORTATION EQUIPMENT IN CHINA 2010-2014

\begin{tabular}{cccccc}
\hline Year & $\mathbf{2 0 1 0}$ & $\mathbf{2 0 1 1}$ & $\mathbf{2 0 1 2}$ & $\mathbf{2 0 1 3}$ & $\mathbf{2 0 1 4}$ \\
\hline RCA index & 1.34 & 1.42 & 1.49 & 1.76 & 1.93 \\
\hline $\begin{array}{c}\text { Data source: arrange and calculate according to Customs Statistics, Yearbook of China's Foreign } \\
\text { Economic Relations and Trade }\end{array}$ & & & &
\end{tabular}

According to "Table I", during 2010 and 2014, the main RCA values of mechanical and transportation equipment are between 1.25 and 1.98 , which indicates that the mechanical and electrical product exporting in China has certain international competitiveness. This trend is mainly influenced by national macro-economic policy. In recent five years, China takes mechanical and electrical industry as important industry target of foreign trade export and provides major support as well as formulates a series of policies and guidelines to encourage the expansion of mechanical and electrical product exporting, in order to make mechanical and electrical enterprises can better participate in international division of labor, strengthen their competitive advantage and improve mode of trade, optimize export structure. Meanwhile, it can promote high-tech mechanical and electrical products to enter international market and gain a firm foothold. The structure of mechanical and electrical product exporting in China will also change from primary finished products to capital and technology intensive finished products.

\section{B. Analysis on International Market Share}

International market share index refers to proportion occupied by export amount of a product in a country in total export of this product in the world. The index reflects international position of a product in a country and shows international competitiveness of a product in a country.

$$
M S=X_{i} / W_{t}
$$

In the formula, Xi refers to export amount of a product in a country, Wt refers to total export of this product in the world.

If MS value is high, it indicates the international export competitiveness of a product in a country is strong. Otherwise, it indicates the competitiveness is weak. Now analyze international market share of main mechanical and transportation equipment in China during 2010 and 2014.

\begin{tabular}{|c|c|c|c|c|c|c|c|c|}
\hline Category & $\begin{array}{c}\text { Automatic Data } \\
\text { Processing } \\
\text { Equipment }\end{array}$ & $\begin{array}{c}\text { Communicati } \\
\text { on } \\
\text { Equipment }\end{array}$ & $\begin{array}{c}\text { Electrical } \\
\text { Equipment }\end{array}$ & $\begin{array}{l}\text { Household } \\
\text { Consumption } \\
\text { Electronic } \\
\text { Products }\end{array}$ & $\begin{array}{c}\text { Lighting } \\
\text { Equipment }\end{array}$ & Electromotor & $\begin{array}{l}\text { Mechanical } \\
\text { Components }\end{array}$ & Ship \\
\hline 2010 & 18.21 & 21.57 & 25.97 & 27.80 & 13.13 & 2.57 & 11.34 & 8.13 \\
\hline 2011 & 19,33 & 22.32 & 26.05 & 27.98 & 13.72 & 4.04 & 12.85 & 9.78 \\
\hline 2012 & 20.25 & 24.24 & 26.34 & 28.22 & 14.04 & 6.26 & 13.43 & 10.43 \\
\hline 2013 & 21.02 & 25.67 & 27.87 & 29.80 & 15.35 & 7.04 & 15.32 & 12.64 \\
\hline 2014 & 24.57 & 26.98 & 28.91 & 30.13 & 16.33 & 7.89 & 17.25 & 14.33 \\
\hline
\end{tabular}

TABLE II. International Market Share of Main MECHANiCAL AND Transportation EQUIPMENT IN China 2010-2014

"Table II" shows: during 2010 and 2014, MS value of mechanical and electrical product exporting in China has obvious advantage. The international market share increases year by year, which indicates that main categories of mechanical and electrical products exported by China take a place in international market on the whole. In 2010, 
international market shares of communication equipment and electrical equipment are $21.57 \%$ and $25.97 \%$ respectively, all exceeding $20 \%$; the international market share of ship changes from $8.13 \%$ in 2010 to $14.33 \%$ in 2014 , with growth rate of nearly $7 \%$. It shows that its international competitiveness increases continuously. The growth rate of household consumption electronic products is about $3 \%$. The growth speed is slow. It indicates that the market share of new hightech products in China still needs continuous expansion.

\section{ANALYSIS ON FACTORS THAT INFLUENCE INTERNATIONAL COMPETITIVENESS OF MECHANICAL AND ELECTRICAL PRODUCTS}

\section{A. Technological Innovative Ability}

Science and technology constitute the primary productive force. Most mechanical and electrical products with relatively strong international competitiveness are new high-tech products. From the perspective of research and development expenditure of mechanical and electrical products, the research and development expenditure of developed countries such as America, Japan and Germany all reaches 500 dollars, which the research and development expenditure of China does not reach 100 dollars. From the perspective of intellectual property of mechanical and electrical products, because of lacking core technology, core mechanical equipment, components and parts, important infrastructure can only completely introduce or copy foreign technology. In the age of technology, foreign market pays high attention to protection of intellectual property. Under the tendency of economic integration, the monopoly of intellectual property and technology of developed countries seriously hinders export competitiveness of promotion of mechanical and electrical products.

According to statistics, the export proportion of high-tech mechanical and electrical products in South Korea, Taiwan and America exceeds $30 \%$. The total proportion of high technology and medium and high technology in China is smaller than total proportion occupied by exporting of mid-low technology and low technology mechanical and electrical products. It shows that the technological innovative ability of China is weak and obviously lower than that of developed countries. The proportion occupied by high technology and medium and high technology in America reaches more than $80 \%$, while the proportion in China is only $50 \%$. Technological innovative ability decides export competitiveness to a certain extent.

\section{B. Brand Awareness}

After joining the WTO, the important reason that influences export competitiveness of mechanical and electrical products in China is that the mechanical and electrical products in China lack self-owned brand and patent consciousness. Most products are introduced from other countries or fake products, which cause all kinds of trade disputes in foreign trade. Meanwhile, because most trade orders are processed by using foreign brands or OEM, it leads to the situation that the proportion of self-owned brand of mechanical and electrical products in China at present is smaller than $10 \%$. Besides, not all brands are related to mechanical and electrical products. In development process of mechanical and electrical product exporting, we can not merely pay attention to quantity, but take the road of sustainable development. In today's world, the export competitiveness of mechanical and electrical products is mainly embodied in brand effect of mechanical and electrical products. Developed countries such as America and Germany focus on brand, set up global system of production and sales through transnational corporations, extend volume growth and promote export growth. From the viewpoint of value chain of international market, brand adopted by research and development and marketing links occupies $70 \%$ of value added. The value added created by production link occupies $30 \%$. If mechanical and electrical enterprises only rely on processing without paying attention to adopting brand, the profit will be reduced greatly.

\section{Market Factors}

In order to prevent spread of core technology, developed countries such as America, Japan and Germany carry out technological monopoly in international high-end machine and electricity market, so the export competitiveness of mechanical and electrical products in many developing countries cannot be promoted. The reason that the export competitiveness of mechanical and electrical products in China cannot be promoted and the export profit cannot increase is that cutthroat competitions such as chaotic export order and price competition often appear in low-end mechanical and electrical product markets of mechanical and electrical product exporting in China.

\section{COUNTERMEASURES TO PROMOTE EXPORT COMPETITIVENESS OF MECHANICAL AND ELECTRICAL PRODUCTS IN CHINA}

\section{A. Improve Technological Innovative Ability}

Technological innovative ability is important factor to influence mechanical and electrical product exporting. Mechanical and electrical industry needs to fully realize importance of technology, actively adapt to tendency of economic globalization and use advantages brought by transnational corporation and improve technology content and additional value of export product. After joining the WTO, because China has advantages of labor force and resources, transnational corporation takes China as new investment market. The whole process from research and development to production and to sales is finished in China, which can save production cost and better meet market demands. When transnational corporations make the best of advantages of China, they will adopt high and new technology that is difficult for mechanical and electrical export enterprises in China to reach in research and development, production, management and marketing channel. Mechanical and electrical enterprises need to communicate and learn core technology to improve innovation capacity of products. In recent years, China carries out industrial transfer with import and export trade markets, changes from vertical machining to horizontal machining. In order to maintain competitive advantage and benefit, developed countries take protective measures to prevent advanced technology owned by transnational corporation from 
losing and spreading, and seriously prevent China from introducing high and new technology from foreign countries. Therefore, export enterprises of mechanical and electrical products shall train consciousness of innovation subject, actively use external available resources and seize opportunity to learn and master core technology. In this process, fully exert function of government, formulate related policies and guidelines, create enabling environment for enterprise innovation, improve related provisions of intellectual property, encourage enterprises to innovate and promote research and development of enterprises.

\section{B. Build Brand Awareness}

Nowadays, science and technology develops rapidly. Living standard of people improves. People pay more and more attention to brand, which becomes important factor to influence corporate performance as well as important strategic index to weigh export competitiveness of mechanical and electrical products. Therefore, mechanical and electrical enterprises need to build brand awareness, create international popularity and attract the attention of more consumers. In this way, they can enter international market faster. Larry Wright, famous American marketing expert, once said, "The future will break out war of brand - competition among brands." Therefore, for export enterprises of mechanical and electrical products, it is very important to build brand competition and develop self-owned brand with market value. Under the influence of global economic integration, mechanical and electrical enterprises need to actively adapt to the trend, take the road of sustainable development, consider with long-term view and build self-owned brands. At the meantime, in order to build good brands, it requires enterprises to realize importance of intellectual property in research and development stage. If independent research and development of mechanical and electrical enterprises maybe misses the opportunity in the market, it is more serious to lack research and development of proprietary intellectual property rights. Brands will not be built perfectly, so that enterprises cannot gain expected benefits. In general, in the process that mechanical and electrical export enterprises cooperate with foreign transnational corporations and groups, it is necessary to seize the opportunity to learn and master core technology of self-owned brand, strengthen contacts and communication in mechanical and electrical industry, build self-owned brand together. Of course, they can intensify cooperation with universities at home and abroad, introduce technical personnel to promote brand development.

\section{Implement Diversified Market Strategy}

From the perspective of domestic market, mechanical and electrical enterprises in China are familiar with domestic consumption market and understand marketing channel. It is the advantage that foreign enterprises cannot compare. Therefore, mechanical and electrical export enterprises in China shall start with basic situation of China, make the most of comparative advantage and exploit and develop markets in developing countries such as the Middle East, Africa and Latin America. In order to better expand the market in developing countries. The most important is to understand and grasp supply-demand relationship in foreign market, seize characteristics of demand and implement diversified market strategy.

\section{CONCLUSION}

Implementing diversified market strategy helps to reduce export risks of mechanical and electrical products and avoid trade dispute of main export markets. Therefore, when consolidating traditional markets in America, European Union, Japan and Hong Kong of China, it also needs to increase the development of emerging markets in South America and Association of Southeast Asian Nations (ASEAN), especially strengthen market relation including ASEAN in Asia.

\section{REFERENCES}

[1] Zhang Xiaoxue, Wu Dan, Zhang Xiaoshuang. Analysis on Export Competitiveness of Mechanical and Electrical Products in China [J], Foreign Economic Relations \& Trade.

[2] Bao Siriguleng, Bao Siqintana. Analysis on International Export Competitiveness of Mechanical and Electrical Products in China [J], Economic Forum, 2014, 9(9): 113-117.

[3] Nie Yang. Analysis on Current Situation of Mechanical and Electrical Products Exporting [J], Macro Economy, 2010, (8): 66-67.

[4] Liu Xiaojiang, Lai Mingyong. Empirical Research on Mechanical and Electrical Products Exporting for Economic Growth [J], Journal of International Trade, 2004, (11): 22-25. 